Faculty of Law, Josip Juraj Strossmayer University of Osijek,

Dražen Tomić, ${ }^{*}$ PhD.

Assistant Professor,

Faculty of Electrical Engineering,

Computer Science and Information Technology,

Josip Juraj Strossmayer University of Osijek,

UDK: 007.52:347.51

Рад примљен: 14.09.2021.

Рад прихваћен: 10.10.2021.

\title{
CIVIL LIABILITY FOR DAMAGE CAUSED BY A ROBOT WHEN PERFORMING A MEDICAL PROCEDURE ${ }^{* *}$
}

\begin{abstract}
Robots in medicine, unlike industrial automation, can be viewed as an extension or enhancement of human capabilities. The legitimacy of robotics in the health care system stems from the fact that its use increases the efficiency of the treatment process and improves the health of an individual. On the other hand, involving robots in the medical procedures brings a high degree of risk and liability for damage. Legal doubts that arising in regard of the use of robots in medicine are related to civil liability for damage caused to the patient during the medical procedure. In that context, it is necessary to determine the model of indemnity liability that applies to damages due to the action of robots in a medical procedure. Which system shall be applied: the system of subjective liability based on fault (guilt), or the system of objective liability without determining the injurer's fault? This issue is gaining in importance given the degree of autonomy of robots in performing medical procedures. The paper will emphasize the need for legislative intervention in the Croatian legal system in order to adapt to the growing use of robots in medicine. The paper will summarize the results of the analysis on these issues and offer possible solutions in court practice and legal dogmatics.
\end{abstract}

Keywords: robot, liability for damage, medicine, guilt, causality.

\footnotetext{
*dpichler@pravos.hr

*drazen@etfos.hr

${ }^{* *}$ This paper was presented at the International Scientific Conference „Law and Digitalization“, held at the Faculty of Law, University of Niš, 23-24 ${ }^{\text {th }}$ April 2021.

The paper is the result of research within the project Substantive and Procedural Civil Law in the 21st Century - Current Situation and Trends in the Future (IP-PRAVOS - 7), funded by the J. J. Strossmayer University in Osijek.
} 


\section{Introduction}

Technological development has led to the application of robotics ${ }^{1},{ }^{2}$ in medicine as one of the most promising areas of application in which significant financial and scientific resources are invested (Boban, 2019: 93). Robotic technology in medicine has been introduced over the last thirty years with the aim of reducing the risk of error and improving the quality of service. Also, surgical robots can be viewed as an extension and enhancement of human capabilities (Cammarilo, Krummel, Salisbury, 2004: 6-10). In terms of the degree of autonomy, several degrees of robot automation can be distinguished with respect to the degree of robot-physician independence: direct control model, shared control, supervised autonomy, and complete autonomy (Vuletić, 2019: 150-151). The most important issues, of theoretical and practical legal significance, are related to the model of complete autonomy of robots in performing medical procedures.

The paper will highlight the issue of determining of the robot's action as an injurious act that causes damage to the patient during the medical procedure and the type of liability for damage applied in litigation for compensation in such cases. The issue of causality as a presumption of liability for damage caused by the robot will be discussed as well. At the end of the paper, the authors urge for special regulations, which would establish liability for damage stemming from the actions of a medical robot, as a model that would be acceptable to both dogmatics and legal practice. In this regard, certain recommendations from international documents that should be a drafted to address these issues will be emphasized.

\section{Development of robotics in medicine}

In the 1940s, the first remote control systems appeared that allowed man to see and feel the tasks he performed remotely. Since then, robots have been used in areas ranging from agriculture, the military, education to surgery. With the development of minimally invasive surgical techniques, in the second half of the 1980s, surgeons no longer had to put their hands into a patient's body to perform a procedure. Robot that assists in performing these procedures will eliminate certain human limitations, such as tremor and limitations of the hu-

1 The term "robot" was coined by the Czech writer Karel Čapek in his 1920 play "Rossum's Universal Robots." It derives from the Czech word "robota", meaning slave labor. (Cammarilo, Krummel, Salisbury, 2004: 3).

2 A robot is defined as any machine that replaces human labor and is controlled automatically although it does not have to resemble a human form or perform functions in a human way. (Chicago, 1998: 116). 
man eye, which will result in improved execution of the procedure (Cammarilo, Krummel, Salisbury, 2004:7).

The first known robot in surgery was the "Arthrobot", which in 1983 assisted in the installation of hip prostheses. The integrated surgical system "Robodoc" was introduced in 1992 for the installation of precise elements in the femur during hip replacement. The "NeuroMate" system in neurosurgery displays real-time 3D images that show the surgeon the precise location of the tumor. The first robot in commercial use was Aesop in 1994, which assisted surgeons as a third hand holding an endoscopic camera. In 1998, the first heart bypass operation was performed, in which the "Da Vinci" robot actively helped surgeons. In 2009, the first fully robot-assisted kidney transplant was performed. Today, robots are used in diagnostics, surgery, rehabilitation and care for the elderly and infirm. Micro and nanorobots are the near future (removal of blood clots, removal of parasites, destruction of cancer cells). The usefulness of using the robots is in a more precise and faster procedure, which leads to faster patient recovery and a shorter stay in the hospital (Kačer, Kačer, 2019: 82). In order to reap the benefits of this promising technology, communication and mutual understanding between physicians, engineers, entrepreneurs and health administration is crucial (Cammarilo, Krummel, Salisbury, 2004: 7).

Four possible levels of robot independence in medicine (primarily surgery) can be highlighted, given the degree of its independence from man (physician). These are: a direct control model, the shared control model, the supervised autonomy model, and the complete autonomy model. In the direct control model, the doctor retains complete control of the machine, which is used as an extension of the doctor's arms. This is still the most common approach today. An example of this system is The Da Vinci Surgical System for Laparoscopic Surgery. In the shared control model, the surgeon and the robot work in a kind of synergy, involving a combination of the doctor's movements on the one hand, and the corresponding robot reactions on the other. The robot corrects the doctor's movements and eliminates defects (e.g. tremor). An example is The Steady Hand Robot, a microsurgical device. The supervised autonomy model means that the robot performs tasks under the supervision of a doctor, who issues orders and supervises the procedure. The robot has a certain autonomy in performing specific tasks, but the doctor supervises the procedure and is able to intervene at any time and direct the robot to work differently. An example is the CyberKnife System. The complete autonomy model is still not in use in modern medicine. In this model, the robotic system completely replaces man. Independently plans and performs medical procedures. It draws the necessary data from the findings of a specific patient. The dominance of such systems is predicted in the near future. The STAR system was introduced in 2017 in the United States when a robot surgeon 
performed surgery, independently of human guidance, on a pig's small intestine faster and more independently than a team of surgeons who performed the same operation on another pig at the same time (Vuletić, 2019: 151). In this paper, we will be considered the civil law aspects of the hypothetical situation when this robot model of robot, in performing a medical procedure, makes the error which results in death or damage to the patient's health.

\section{Robotic systems - operation, management, capabilities and development}

One of the important goals of robot application is to shorten the duration of surgical procedures compared to classic manual procedures, however, this goal has not yet been achieved in most areas of application (Gomes, 2011: 261-266). The use of robots has evolved from an initial application to support, move, and control the camera in the operating field to complex applications in which the physician operates from a greater distance using a control console. In doing so, the physician uses advanced computer technologies that, in addition to surgical robots, include the use of 3D images, computer graphics and computer simulators (Hashizume, Tsugawa, 2004: 227).

The advantages of robots, which include accuracy and repeatability of movement, have significant application in industry; the application in medicine is difficult because this area is not as precise and structured as industrial application. The main disadvantages of robots in surgical procedures are low adaptability and low level of feedback on the applied force.

From the very beginning of robotics, people were aware of the fact that robots, in addition to performing useful work for which they were made, can also harm humans. This area was regulated by the first three laws of robotics regulated this area (Asimov, 1942: 94-103), which are still relevant and ethically acceptable for the development of medical robots:

1. A robot must not injure a human being or, by inactivity, allow injuries to occur.

2. A robot must obey all orders given to it by humans, unless such orders would conflict with the First Law.

3. A robot must protect its existence, unless it conflicts with the First or Second Law.

These laws of robotics are applied primarily in the design and manufacture of robots, but it does not include cases where robots are used against their purpose 
or when an unintentional error occurs in the operation of a robot, which can be classified into three basic categories:

a) Mechanical error - malfunction or non-functionality of a certain part of the tool / robot;

b) Software error - an error in a computer program that controls a procedure or a computer program that controls a certain part of a tool / robot;

c) Artificial intelligence decision error - an error in decision making made by a robot based on information it has about: the patient's previous health, current status of the procedure that it performs or the database available for decision making. This type of error will begin to occur with the application of artificial intelligence and robotic vision in robot control.

Robotic systems in medicine can be implemented in the form of automatic hands, mobile devices or telerobotic systems. As for the taxonomy of robots, they can be active, semi-active or passive. Semi-active and passive robots transmit operator commands and movements to the robot's hands. Active robots are those that have a predefined schedule and work on a computer algorithm, without the need for the operator's intervention in real time (Hockstein, Gourin, Faust, Terris, 2007: 114). In this context, although surgical robots can be classified by multiple criteria in this context, the most acceptable classification is according to the role the robot plays during the operation. According to this classification, passive robots perform low-risk maneuvers and perform simple precise tasks. Active robots are significantly involved in intervention while limited-role robots perform tasks and invasive maneuvers with a higher risk than those with a passive role but with lower risk than those with an active role. According to this classification we can conclude that as the autonomy of the robot increases, the role of the robot changes from active to passive; thus, the most passive robots used for medical purposes have greater autonomy but a very low risk during use, while surgical robots that have an active role during the procedure have the least autonomy because they are exposed to increased risk during the procedure. Although active-role robots are superior to passive ones, in their application the situation is reversed in their application because active robots perform high-risk tasks which require human supervision and significant human intervention during the procedure, as compared to passive robots, which operate autonomously and can perform tasks without supervision but in for activities that have very low or no risk (Cammarilo, Krummel, Salisbury, 2004:7). Most, if not all, of the currently available robotic systems function only as robotic aids during medical procedures, acting as a mechanism to guide the procedure or as a protective mechanism for patients while providing additional features (such as 
hand movement filtering or force scaling) but fully automated robotic surgery is still not possible (Ginoya, Maddahi, Zareinia, 2021: 11).

In the future, a greater use of miniature mobile robots is expected for applications in specific areas, such as invasive therapy on the surface of the beating heart, while nano and micro robots, which could be swallowed or inserted into the bloodstream, are still at the level of an idea. It envisages the use of miniature robots equipped with several types of sensors, which can provide important information about the patient's condition in real time. Robotic systems controlled by artificial intelligence could also be developed; they perform surgery without the need for the presence of a surgeon or only under their supervision. In doing so, machine learning methods are used where data are collected by studying the work of surgeons, because using only programmed behavior is not enough because engineers do not know and cannot know all scenarios of possible events. Thanks to the collected data and complex algorithms, artificial intelligence can determine patterns within surgical procedures to improve best practices and improve the accuracy of control of surgical robots to submillimeter precision. Artificial intelligence also uses machine vision to analyze scans and detect diseases; laparoscopic video analysis of operations helps identify missing or unexpected steps in real time. The application of clinically feasible surgical robots is likely to happen by the end of the 21st century. The combination of artificial intelligence with surgical robotics can increase surgical ability to optimize the outcome of surgery and provide increased access to health care (Panesar, Cagle, Chander, Morey, Fernandez-Miranda, Kliot, 2019: 226).

\section{Injurious act}

An injurious act of the injurer is a precondition for the occurrence of liability for damage. (Klarić, Vedriš, 2006: 583). An injurious act is any act or omission of a injurer that causes damage of the injured party. An action that originates from a natural force, an animal, or a machine is not a human action. The movements of the machine are considered to be the action of the machine owner or the machine handler (Klarić, Vedriš, 2006: 90).

In the provision of health services, the most important injurious act and omission refers to the violation of the rules of the health profession (medical error). ${ }^{3}, 4$

3 Other injurious actions and omissions that occurs in the provision of health services include: violation of the right to physical integrity (treatment without patient consent), violation of the obligation to provide emergency medical care and violation of the obligation to contract a health service agreement (Klarić, 2003: 398).

4 The term "medical error" was created by the famous pathologist Rudolf Virchow and defined as a violation of generally accepted rules of the art of treatment due to lack of due 
The concept of medical error is today replaced by the concept of error in treatment, which includes errors in diagnosis, prophylaxis and follow-up care; it is defined as a measure that represents neglect or deviation from the medical standard and is performed without due care. Medical error and guilt should be treated as two separate presumptions of liability for damage which, according to the rules of fault liability, must be cumulatively fulfilled. Based on the opinion of the medical expert, the court will determine whether there was a deviation from the medical standard in the specific case, and then whether the doctor is to blame (Klarić, 2003: 398).

A special issue of liability for injurious acts arises in cases involving Artificial intelligence-based diagnostic systems (AIBDS). ${ }^{5}$ Artificial intelligence systems are the product of the work of a large number of experts. When the operation of such a system results in a harmful consequence, the problem of "distributed liability" may arise, which entails a situation in which the harmful consequence can be attributed to the collective (team or institution) and not to a particular person individually. In such cases, it may not be possible to find a single culprit (as liability may be shared between the programmer, sensor designer, hospital management). In such a situation. it is clear that the physician will be primarily identified as a injurer and may, therefore, be reluctant to use AIBDS (Bracanović, 2021: 73).

\section{Damage liability model}

The importance of choosing the rules of subjective liability or liability without fault for damage is expressed in the question whether, in addition to unlawfulness in the objective sense, fault as a subjective element of unlawfulness will be required as a presumption of liability (Klarić, 2003: 390). In the Croatian legal system, as a rule, a subtype of subjective liability is applied in which the guilt of the injurer is presumed. The injured party must prove the injurious act, the damage, and the causation, while the guilt of the injurer is presumed. However, the lowest degree of guilt is presumed, and that is ordinary negligence. The injured party is required to prove any higher degree of guilt, such as intent and gross negligence (Klarić, Vedriš, 2006: 610). Also, the Obligation Relations Act ${ }^{6}$ stipulates that the party in the obligation relationship is obliged to act with rea-

care. In medical and legal terminology, it is also designated as: professional error, harmful event. (Klarić, 2003: 398).

5 In addition to the above, terms such as "Machine Learning Expert Systems" or "Expert Diagnostic Systems" are also used, but we use the abbreviation AIBDS as an internationally accepted abbreviation. (Bracanović, 2021: 64).

6 Art. 10, para 2, Obligation Relations Act, Official Gazette of the Republic of Croatia, No $35 / 05,41 / 08,125 / 11,78 / 15,29 / 18$, hereinafter ORA. 
sonable diligence, in line with the rules of the profession and customs (with due care of a good expert) in fulfilling the obligation from the professional activity (Crnić, 2006: 8). Thus, for health care professionals, this provision establishes that the measure of their professional diligence is determined based on two criteria: the persons from their professional circle and the specific circumstances of the medical intervention (Klarić, 2003: 401). In this sense, it is necessary to take as a criterion the diligence of an experienced and conscientious health care worker of the same category and rank as the one whose diligence is being evaluated: general practitioner, specialist (Klarić, 2003: 401).

Subjective liability for damage, especially in the area of liability for damages in medicine, can raise certain objections. Thus, in case of subjective liability, it is emphasized that the doctor's guilt must be proven. The patient's position here is particularly difficult since, as a non-expert, he must prove a violation of the rules of a highly specialized activity, and the presence of a causation ${ }^{7}$ between a medical error and the sustained damage. This is particularly problematic given that the experts in these cases are physicians, whose impartiality, for obvious reasons, may be called into question (Klarić, 2003: 392). The system of subjective liability for damage shows no signs of a reduction in the number of court proceedings. On the contrary, the number of court proceedings is constantly growing with the increase in health care costs (Kessler, P. D., 2004: 3).

\subsection{Liability without fault system}

Due to the above, there is an increasing tendency to introduce the system of strict liability for damage in medicine. In the system of strict or causal liability, no guilt of the injurer is required for the occurrence of liability for damage. Thus, liability for damage arises when the preconditions are met: an injurious act, sustained damage, the unlawfulness of the injurious act and the causal link between the injurious act and the damage. In case of damage caused in connection with a dangerous object or dangerous activity, the injured party does not have to prove the causality, but it is presumed (Klarić, Vedriš, 2006: 613). In relation to the damage that occur in medicine in connection with a dangerous object or dangerous activity, the tendencies for the application of strict liability for damage are the most intense. This is based on the reasons for the increasing use of certain

7 A causation is a connection that must exist between a injurious act and the damage so that the damage occurs as a consequence of the injurious act. By the nature of things, damage is the result of a multitude of causes. From that multitude, the one who is legally decisive should be chosen. In this sense, we apply the view of adequate causality, that is, of the many circumstances related to the occurrence of damage, the cause is considered only that which in the regular course of things (which is common in life) leads to such a consequence. The injured party must prove the existence of such a causal link (Crnić, 2006: 705). 
devices and the introduction of technology in medicine that did not even exist until recently (laser, robotic surgery, radiation, etc.) the consequences of which are not yet completely predictable. In the case of artificial intelligence systems, there is also the so-called problem of "inexplicability." Due to the complexity and the amount of data used by the system, designers of such systems will not be able to know how the system came to a particular solution. Such a system is not programmed with rules for solving problems but creates such rules itself during the process of "learning" and previous work. Such a system may also fail to reveal some obvious and extremely important causal links important for the patient's health. ${ }^{8}$

In this sense, and in the countries that consistently apply the rules of subjective liability, there is increasing insistence on the introduction of strict liability for damages caused by medical devices (Klarić, 2003: 395). In the Republic of Croatia, the legal basis for the application of strict liability for damage in medicine was established in the the Obligation Relations Act (ORA); it is based on liability for damage arising from things or activities which the increased risk of damage to the environment originates from. The one who operates such a thing or is involved in such an activity is liable regardless of guilt (Article 1045, para. 3 ORA). Thus, in Croatian tort law there is a legal basis for the application of strict liability. It is necessary for the court, in each individual case, to determine whether a certain thing or activity which gave rise to certain damage has occurred is a thing or activity from which the increased danger of damage to the environment originates. In that case, court must apply the rules of strict liability. ${ }^{9}$

Legal judgements on the recognition of patients' right to compensation by applying the principle of strict liability are accepted in Croatian legal theory and case law. Thus, it is pointed out that medical devices are the basic hospital assets of the hospital on the basis of which the hospital performs its activities and generates income. In this sense, it is also fair that the one who obtains a

8 Today's medicine is often based on experiential observations that are not simultaneously accompanied by appropriate understandings of the relevant causal relationships that make a particular intervention successful and effective. Examples are aspirin (which has been prescribed as an analgesic for a hundred years, although the mechanisms of its action have not been explained) and lithium (which is used as a mood stabilizer, although it is not entirely known how it works). (Bracanović, 2021: 66-74).

9 Judicial practice and legal theory define the concept of a dangerous object as one that by its purpose, characteristics, position, place and manner of use or otherwise represents an increased risk of damage to the environment, and therefore should be monitored with increased attention. A dangerous activity is an activity which, in its regular course but by its very technical nature and manner of performance, may endanger lives and health of people or property, so that such endangerment requires increased attention of persons performing that activity and persons who come in touch with it (Klarić, Vedriš, 2006: 615). 
benefit by performing an activity, which due to its danger carries an increased risk of harm to other persons, compensates for the damage caused by that activity (Klarić, 2003: 394).

Given the current degree of autonomy of robots in medicine, it is clear from the aforesaid that the conditions for the application of the rules of strict liability are met. As specified in the ORA, the owner of the object is liable for damage stemming from dangerous objects, and the person handling such objects is liable for damage stemming from dangerous activities (Art. 1064, para. 3 ORA). Thus, in practice, in the Republic of Croatia, this practically means the liability of hospitals owned or founded by the state or a unit of local or regional government (Kačer, Kačer, 2019: 84). Instead of the owner of the thing, the person who is also responsible is the person to whom the owner has entrusted the thing (Art. 1066 para. 1 ORA). Thus, when the owner handed over a dangerous object to a third party based on, for example, a lease, loan or leasing contract that party will be liable. (Crnić, 2006: 765). If the injured party is unable to file a claim against the health facility, he/she may file a lawsuit against the device manufacturer and/or the robot owner. ${ }^{10}$

\section{Special regulation?}

Due to the complex legal position of the injured party, in cases where the damage is caused by the action of a medical robot, in the Recommendations to the Council of Europe member states, the Commissioner for Human Rights emphasizes the obligation of member states to ensure access to an effective legal remedy for all those who suspect that they have been the subject of a measure entirely or substantially based on the operation of an artificial intelligence system. Effective remedies should also include adequate compensation and modification of any damage caused by the development, putting into use, or use of an artificial intelligence system; they may also include measures envisaged in civil or administrative law. In this regard, Member States should evaluate the existing laws, including civil, criminal and administrative laws, and introduce reforms where these regulations do not provide an effective remedy for those who claim to be victims of human rights violations arising from the development, putting into use, or use of the artificial intelligence system (Commissioner for Human Rights, 2019: 13-22).

10 In such a situation, it should be noted that the liability for damage is that of a legal entity which is established with an amount of share capital that is not sufficient to cover the amount of damages: there is no liability of the founders and persons authorized to represent such a legal entity. It is clear then that the occurrence of compensation for the injured party is minimal (Kačer, Kačer, 2019: 85). 
The reform of the liability system would reduce healthcare costs and allow patients to compensate the damage which they sustained. In the Scandinavian countries, New Zealand and the United States, there is an alternative to the existing systems: the principle of patients' compensation called "no fault - no guilt" or "no fault compensation scheme". The patient is compensated for damage based on physical or mental injury upon proving causation between the medical service and the injury. Non-property and property damage is compensated. The medical staff reports the injury, but the patient can also contact the insurer directly. If the patient is dissatisfied with the amount of compensation assigned to him, he/she has the right to file a claim; however, in case of losing the case, he/she is exposed to the risk of paying the costs of the procedure. It is an administrative, not a civil procedure (Proso, 2009: 363-364). ${ }^{11}$

As a possible solution to the damage caused by a robot, it is proposed to form a special fund to compensate for the damage caused by a robot. The liability for damage would be based on the strict liability system, i.e. the fact that the damage was caused by a robot. The fund would be financed by contributions from manufacturers, programmers, and sellers. Part of the fund, unspent for damages, could be reinvested in further technological research and development. In the practice of some insurance companies, the most prominent reasons for excluding the insurer's obligation are infection with a computer virus and failure to recognize the date which contributed to causing damage (Jovanović, 2018: 129-130). What all no-fault systems have in common is that medical errors must be registered. This is because the record on the occurrence of the error and the consequence it caused has the purpose of avoiding a similar situation in the future. The system requires the registration of every error and reporting on every technical defect. The introduction of computerization, procedures for diagnostic and therapeutic measures, and error registration systems enables the analysis and taking measures to ensure that medical errors do not recur (Jovanović, 2018: 129-130).

11 Compulsory no fault patient insurance was introduced in Sweden as early as 1975. Other Scandinavian countries have very similar models of patient compensation systems. In Finland, this system was introduced in 1970, first as a voluntary one, and since 1980 as a mandatory one. Norway passed similar legislation in 2003. The Swedish model of patient insurance has served as the basis for law-making in Denmark. The United States has reached unprecedented levels of health care costs with no signs of slowing growth, resulting in the practice of "defensive medicine," or the use of treatment options that are not necessarily in the best interests of the patient but protect physicians from potential litigation. The system reimburses the plaintiff for medical expenses and reasonable legal fees. The no-fault system has been accepted by Florida and Virginia to a limited extent for certain neurological impairments related to childbirth. The system in Virginia also allows for compensation of lost earnings for people aged 18-65 in the amount of 50\% of the average wage (Pichler, 2020: 44-45). 


\section{Conclusion}

The effects of artificial intelligence on personality rights are one of the most important factors that will define the period in which we live (Commissioner for Human Rights, 2019: 5). The law of robotics, which has yet to be built into a separate branch of law, must de lege ferenda provide answers to a number of questions, such as: the legal status of autonomous robots, the liability of robot manufacturers and owners, and other issues of a pecuniary nature (Jovanović, 2018: 118). In this sense, the importance that robotic systems already have in medical applications has been recognized, ${ }^{12}$ but there are also highlighted concerns about the risks and negative impacts associated with the application of robotic technology in medicine. The paper analyzes robotic systems in medicine, their operation, control, capabilities and development.

The inevitable increase in the degree of robotization in medicine will lead to an increasing number of cases involving violations of patients' physical integrity and an increase in claims for damages. For this reason, it is important that case law and jurisprudence take a position on the application of an appropriate model of liability for damage which will be applied in these cases. This is of particular importance for the protection of patient personality rights, the uniform application of the law and legal certainty.

Therefore, the paper attempts to highlight some neuralgic points in the problem of liability for damage caused by a robot during medical intervention. The advantages of applying the system of strict liability for damage stemming from a dangerous object or a dangerous activity have been pointed out. A special feature of the so-called "no-fault" systems is the registration of medical errors and reporting on technical deficiencies in order to avoid similar situations in the future. The introduction of informatization enables the analysis and taking measures so that medical errors do not recur. These compensation systems aim to ensure both fast and fair financial compensation without lengthy court proceedings and high costs. The proposed solution de lege ferenda is a system of compulsory robot insurance, analogous to compulsory car insurance. Manufacturers, programmers, owners and users of robots shall be obliged to pay insurance premiums.

12 The importance of the application of robots and artificial intelligence systems will become increasingly important especially in the context of an aging European population, including the role of robotic systems in provision of care for the elderly and real-time patient monitoring. In the provision of health care in the future, robotic systems will be entrusted with the role of conducting targeted medical treatments and the so-called tailored treatments (European Commission, 2019: 32-35). 
In any case, no matter which model of liability for damage caused by robots during the medical procedure we choose to apply, it must not discourage innovation in the field of artificial intelligence, which must be in line with the goals of sustainable development. In other words, the development of artificial intelligence must be consistent with the protection of the rights of the individual and the rule of law in every legal order.

\section{References}

Asimov, I. (2019). Runaround. In: Astounding Science Fiction. New York: Street \& Smith Publication Inc. (94-103).

Boban, M. (2019). Uporaba robotike u medicini: tehnološki, pravni i etični izazovi. U S. Kraljić, J. Reberšek Gorišek, V. Rijavec (Prir.), Globalizacija medicine v 21. stoletju. (89-107). Maribor: 28. posvetovanje Medicina, pravo \& družba.

Bracanović, T. (2021). Umjetna inteligencija, medicina i autonomija. Nova prisutnost. XIX(1). (63-75).

Camarillo, M. S., Krummel, T. M., Salisbury, K. J. (2004). Robotic technology in surgery: past, present, and future. The American Journal of Surgery. 188(4). (2-15).

Commissioner for Human Rights. Council of Europe. Unboxing Artificial Intelligence: 10 Steps to Protect Human Rights. (2019).

Crnić, I. (2006). Zakon o obveznim odnosima Napomene, komentari, sudska praksa i prilozi. Zagreb: Organizator.

European Commission. Ethics Guidelines for Trustworthy AI. (2019).

Ginoya, T., Maddahi, Y., Zareinia, K. (2021). A Historical Review of Medical Robotic Platforms, Journal of Robotics. Vol. 2021, 13 pages.

Gomes, P. (2011). Surgical robotics: Reviewing the past, analysing the present, imagining the future. Robotics and Computer-Integrated Manufacturing. 27(2). (261-266).

Hashizume, M., Tsugawa, K. (2004). Robotic surgery and cancer: the present state, problems and future vision. Japanese Journal of Clinical Oncology. 34(5). (227-237).

Hockstein, N. G., Gourin, C. G., Faust, R. A., Terris, D. J. (2007). A history of robots: from science fiction to surgical robotics. Journal of Robotic Surgery. 1(2). (113-118). 
Jovanović, S. O. (2018). Izazovi pravnog regulisanja robota i osiguranja od šteta prouzrokovanih njihovom upotrebom. [Electronic version]. Retrieved 30, August 2021, from 18-03_4.pdf (tokoviosiguranja.edu.rs)

Kačer, H., Kačer, B. (2019). Robotika i umjetna inteligencija u medicini - građanskopravni aspekti odgovornosti za štetu. U S. Kraljić, J. Reberšek Gorišek, V. Rijavec (Prir.), Globalizacija medicine v 21. stoletju (71-88). Maribor: 28. posvetovanje Medicina, pravo \& družba.

Kessler, P. D. (2004). The effects of the U.S. Malpractice System: A Reviev of the Empirical Literature. New York: Manhattan Institute.

Klarić, P. (2003). Odštetno pravo. Zagreb: Narodne novine.

Klarić, P. (2008). Građanskopravna odgovornost za liječničku grešku. U J. Barbić (Ur.), Građanskopravna odgovornost u medicini. Zagreb: Hrvatska akademija znanosti i umjetnosti - Znanstveno vijeće za državnu upravu, pravosuđe i vladavinu prava.

Klarić, P., Vedriš, M. (2006). Građansko pravo. Zagreb: Narodne novine.

Panesar, S., Cagle, Y., Chander, D., Morey, J., Fernandez-Miranda, J., Kliot, M. (2019). Artificial Intelligence and the Future of Surgical Robotics. Annals of Surgery. Vol. 270 Issue 2 (223-226).

Pichler, D., Vuletić, I. (2020). Građanskopravni i kaznenopravni aspekti pogrešaka u medicini. Osijek: Pravni fakultet Sveučilišta Josipa Jurja Strossmayera u Osijeku.

Proso, M. (2009). Sustavi osiguranja od odštetne odgovornosti u zdravstvenoj djelatnosti. Zbornik radova Pravnog fakulteta Sveučilišta u Splitu. 2/2009. (359372).

The New Encyclopaedia Britannica (15th ed.) (1998). Chicago, USA: Encyclopaedia Britannica, Inc.

Vuletić, I. (2019). Kaznenopravni aspekti razvoja umjetne inteligencije u medicini:tko je odgovoran za pogrešku u liječenju koju počini autonomni robotkirurg? U S. Kraljić, J. Reberšek Gorišek, V. Rijavec (Prir.), Globalizacija medicine v 21. stoletju. (145-165). Maribor: 28. posvetovanje Medicina, pravo \& družba.

Zakon o obveznim odnosima (Obligation Relations Act), Narodne novine br.35/05, 41/08, 125/11, 78/15, 29/18. 


\section{Dr. sc. Davorin Pichler, \\ Izvanredni profesor, \\ Pravni fakultet, Sveučilište Josip Juraj Strossmayer u Osijeku, \\ Dražen Tomić, PhD., \\ Docent, \\ Fakultet elektrotehnike, računarstva i informacijskih tehnologija, \\ Sveučilište Josip Juraj Strossmayer u Osijeku, \\ Republika Hrvatska}

\section{GRAĐANSKOPRAVNA ODGOVORNOST ZA ŠTETU KOJU POČINI ROBOT PRI VRŠENU MEDICINSKOG ZAHVATA}

\section{Rezime}

Roboti u medicini, za razliku od industrijske automatizacije, mogu se promatrati kao produženje ili pojačanje ljudskih mogućnosti. Legitimitet robotike u sustavu zdravstva proizlazi iz okolnosti da se njezinom uporabom povećava efikasnost postupka liječenja i poboljšanje zdravlja pojedinca. S druge strane, involviranje robota u postupak medicinskog zahvata donosi visok stupanj rizika i odgovornost za štetu. Pravne dvojbe koje se javljaju po pitanju korištenja robota u medicini odnose se na građanskopravnu odgovornosti za štetu koja nastane pacijentu pri obavljanju medicinskog zahvata. Pri tome je potrebno utvrditi model odštetne odgovornosti koji se primjenjuje na štete uslijed djelovanja robota u medicinskom zahvatu. Hoće li se primjenjivati sustav subjektivne odgovornosti koji se temelji na krivnji ili sustav objektivne odgovornosti bez utvrđivanja krivnje štetnika? Ovo pitanje dobiva na značaju s obzirom na stupanj autonomije robota u izvođenju medicinskog zahvata. U radu će se istaknuti potreba za zakonodavnom intervencijom u hrvatskom pravnom sustavu kako bi se prilagodilo sve široj upotrebi robota u medicini. U radu će se sažeti rezultati analize navedene problematike i ponuditi eventualna rješenja u sudskoj praksi i pravnoj dogmatici.

Ključne riječi: robot, odgovornost za štetu, medicina, krivnja, uzročnost. 